\title{
AGRARIAN STRUCTURE CHANGES IN THE VILLAGE FARMSTEADS ON DURMITOR
}

\author{
Darko Stijepovic ${ }^{1}$ \\ *Corresponding authorE-mail: agrobiznis@t-com.me
}

\begin{abstract}
A R T I C LE IN F O
A B S T R A C T

Original Article

Received: 12 February 2020

The paper presents findings about agrarian structure changes that have occurred in the village farmsteads on Accepted: 01 December 2020 doi:10.5937/ekoPolj2101011S

UDC 316.324.5:711.437(497.16 Durmitor)

Keywords:

agrarian structure, sheep balance, cattle balance, total available land, total utilised agricultural land

JEL: C41, J21, O11, Q15 Durmitor highlands considering thesis that this area has experienced complex and strong changes. The most important characteristics of these changes relate with, aging, de-agrarian striving; and reduction of the livestock fund, land surfaces and number of homesteads.

The agrarian structure of the Durmitor area, which includes the municipalities of Žabljak, Šavnik and Plužine, is characterized by the dominant participation of individual farms focused on sheep and catlle production. The structure of agricultural land use in the examined region was defined by natural conditions and natural way of production. In the total agricultural area, natural meadows and pastures occupy over $90 \%$ of the area, and arable land and orchards occupy a small percentage of the area.The existing land structure determined livestock production as the basic production.
\end{abstract}

(C) 2021 EA. All rights reserved

\section{Introduction}

Wider area of Durmitor is distinguished by many characteristics as one specific geographical and agricultural region with all the features of extensive production and it is naturally predestined and mostly oriented to cattle breeding. This area includes completely or partially the following municipalities of the northern Montenegro: Žabljak, Plužine and Šavnik with approximately one third of the total surface of Montenegro. Today, about 3\% of the total population of Montenegro lives in the given area, of which over $50 \%$ is agricultural, in contrast to the republic where only $15 \%$ is the agricultural population. However, the agriculture is the basic branch of economy for other branches are still poorly developed here. The under development of the economy in this region is visible upon participation of agriculture and forestry in the national income. According to the statistical data 2010 the agriculture and forestry participate in the national income in Montenegro with $28.1 \%$ and private agriculture sector with

1 Darko Stijepović, MSc, Advisor in the Municipality of Žabljak, Address: Javorje bb Žabljak, Phone: +382 69106 666, E-mail: agrobiznis@t/com.me, ORCID ID (https://orcid.org/00000001-8832-7531) 
$25.2 \%$, while in the region of Durmitor this participation is about $43 \%$ or $35 \%$. Of course, there are significant variations in the region regarding development of the economy in its certain parts and intensity of the agriculture. Generally, it can be stated that economy is more developed and agriculture more intensive in the lowland villages of Durmitor contrary to the highlands.

\section{Materials and methods}

The goal of the research is monitoring the state of agrostructural changes in the Durmitor area in the period from 1991 to 2016. Data from the Statistical Office of Montenegro and the Federal Statistical Office of the Republic of Yugoslavia were used to achieve the set research goal. The sources of statistical material were data from the Census of households and dwellings in 1991 and 2003, which referred to the agricultural sector, specifically households, agricultural holdings by size of property and sources of income, and agricultural funds. Data for 2010 are from the Census of Agriculture, and refer to the structure of agricultural holdings: livestock, used land and households. Data for 2016 are preliminary data from the Statistical Office obtained on the basis of a survey on the structure of agricultural holdings, where a two-stage stratified sample without repetition was applied with census districts as primary and households as secondary units. Data related to individual municipalities are unofficial and were obtained by the Statistical Office. For that purpose, a comparative analysis of annual statistical data was performed in order to show agrarian structural changes on farmhouseholds.

The following hypothesis is set in the paper „The size of agricultural holdings significantly determines and conditions the representation of land areas, where it is assumed that the highest concentration will be within the group of farms with medium land holdings from 10 to 15 ha. Significantly, the size of holdings will cause changes in the number of heads, on average per farm and per hectare of agricultural land, in a way that with the increase in holdings per farm, the number of head of livestock will also increase".

In accordance with the established hypothesis and the scientific goal studied in this paper, the relevant quantitative and qualitative methods were applied, as well as the procedures of analysis and synthesis of processes and tendencies that take place under the influence of the ownership structure of agricultural holdings.Quantitative analysis of production resources and agricultural potentials in the observed period included an absolute analysis in hectares, and a relevant one that referred to the percentage of the total represented areas.This analysis was necessary for a quantitative assessment of the current trends and the state of the agricultural structure.

In connection with the study of relevant internal factors of farms, especially the size of holdings and land used in production, the procedures of groupingof rural farms according to several criteria were applied, such as: size of land holdings, share and structure of labor force, and share of livestock. Accordingly, appropriate statistical procedures are applied, such as mathematical and statistical methods, in order to see the mutual reciprocity. They were applied in order to make a comparison between the 
intensity of phenomena by groups of farms that were analyzed. Based on quantitative and qualitative analyzes, with the application of statistical procedures, a performed synthesis confirmed the hypothesis and considered the answers to the questions posed in the research. The results were interpreted in accordance with the criteria, and in order to achieve better visibility, they are presented in tabular form.

\section{Results of the research - Some indicators with individual farmsteads as subjects of production}

Individual farmsteads in this region represent important subject of the agricultural production. Having in mind this fact we can ask what is the supply in these homesteads with the work force, means of work, land capacities, livestock and what is the economic power of these households. Analyzing all these indicators, together with other already mentioned factors, we will get better insight in this production subject and its potentials for higher goods production. In the former paragraph were raised some general conditions and factors in the agrarian landscape of this region and their effects to the livestock breeding in the individual sector, while here we wish to discuss about basic structures of the individual homesteads making their production within such settings. Sources of data for this work are census of the agricultural households 1991, 2003, 2010, and 2016. These collections can fully serve for exploration of the main structural framework features in the individual households when it is in question supply with land, livestock or means of work.

The importance for studying changes in the ownership structure was the selection of methods on which the analysis on the impact of the size of the land ownership on agricultural production processes was carried out. The subject of the research was agrostructural balances, which related to: household fund, population structures, land and livestock. All holdings are grouped according to the size of the landed property into the following groups: for the total holding, without land, then 1 ha, from 1 to 3 ha, 3 to 5ha, 5 to 8 ha, 8 to 10 ha, 10 to 15 ha, 15 to 20 ha and over 20 ha. The statistical method interpreted the numerical data obtained during the survey using certain statistical indicators, depending on the availability of data from both primary and secondary data sources. Agriculture is subordinated to the natural conditions rather than to the market. The natural conditions determine the production structure and the yield are mostly depended on the climatic factors since technology survived in the same form as supply of the household with the means of work.

One of the facets of the individual household regarding organization of the goods production and increase of the income and existence of the family is supply of the household with land surfaces. This aspect is particularly interesting in conditions of extensive agricultural production as in this case study.

However, supply with land surfaces still keeps higher significance in the areas with intensive production since technique and technology are not widely implemented in the practice of these homesteads and natural and economic conditions survived as demanding and unfavourable and they will be the same in the future. 
Table 1.Total household and holdings

\begin{tabular}{|c|c|c|c|c|c|c|c|c|}
\hline \multirow{2}{*}{$\begin{array}{c}\text { TYPS OF } \\
\text { HOUSEHOLDS } \\
\end{array}$} & \multicolumn{2}{|c|}{1991} & \multicolumn{2}{|c|}{2003} & \multicolumn{2}{|c|}{2010} & \multicolumn{2}{|c|}{2016} \\
\hline & 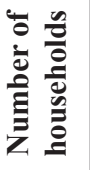 & 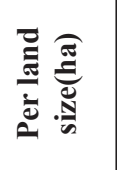 & 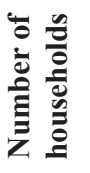 & 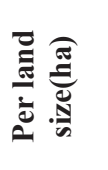 & 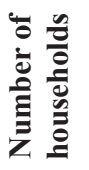 & 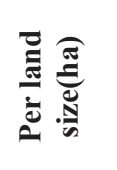 & 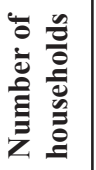 & 疍 \\
\hline TOTAL DOMESTIC & 4053 & $<1->20$ & 3619 & $<1->20$ & 3108 & $<1->20$ & 3027 & $<1->20$ \\
\hline Represented & 709 & $1-3$ & 694 & $1-3$ & 658 & $1-3$ & 702 & $1-3$ \\
\hline Represented & 223 & $15-20$ & 194 & $15-20$ & 9 & $15-20$ & 156 & $15-20$ \\
\hline $\begin{array}{l}\text { A GR IC ULT U R A L } \\
\text { HOUSEHOLDS }\end{array}$ & 2659 & $<1->20$ & 2210 & $<1->20$ & 2282 & $<1->20$ & 2242 & $<1->20$ \\
\hline Represented & 636 & $1-3$ & 694 & $1-3$ & 600 & $1-3$ & 650 & $1-3$ \\
\hline Represented & 42 & - & 90 & $15-20$ & 35 & - & 33 & - \\
\hline $\begin{array}{lcccc}\text { M } & \text { I } & \text { X } & \text { E } & \text { D } \\
\text { HOUSEHOLDS } & & \end{array}$ & 558 & $<1->20$ & 564 & $<1->20$ & 314 & $<1->20$ & 297 & $<1->20$ \\
\hline Represented & 150 & - & 157 & - & 81 & - & 80 & - \\
\hline Represented & 8 & $>20$ & 23 & $>1$ & 6 & $>20$ & 6 & $>20$ \\
\hline $\begin{array}{l}\mathrm{N} \\
\text { A GRIC ULT UR A L } \\
\text { HOUSEHOLDS }\end{array}$ & 836 & $<1->20$ & 845 & $<1->20$ & 512 & $<1->20$ & 488 & $<1->20$ \\
\hline Represented & 280 & 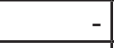 & 263 & - & 148 & $\theta$ & 139 & - \\
\hline Represented & 32 & $3-5$ & 50 & $>20$ & 1 & $>20$ & 1 & $>20$ \\
\hline
\end{tabular}

Source: Population, households, dwellings and agricultural holdings Census in 1991 and 2003, Agriculture Census 2010- structure of agricultural holdings, Press release No. 234: "Structure of agricultural holdings in 2016 (p) 1", Statistical Office - MONSTAT

Table 1. Illustrates that total number of the households was the highest in 1991 (4053) and the highest concentration was in the category of the land ownership of 1-3 ha with 709 in total or $17.49 \%$. Total number of the households in 2016 was 3027 representing $25 \%$ less when compared with 1991. In this year the highest concentration of the households was also in the category of the land ownership of 1-3ha with 702 in total or $28 \%$, while the lowest concentration was in the category of the land ownership of $15 / 20$ ha (156). Total number of the village households in 1991 was 2659 and this is the highest number of all examined years. In the light of this data, the highest concentration of the households in the category of 1-3 ha of the land ownership is with 636 units or $23 \%$. The number of the agricultural households in 2016 was 2242 and this represents $74 \%$ of total number of households and $15.68 \%$ less in comparison with 1991.

The highest concentration of the households is in the category of 1-3 ha with 650 units or $28.88 \%$. Mixed households of total number of the households in 1991 were represented with 13\% and in 2016 with 9\%. The non-agricultural households in 1991 were in 836 units or $20 \%$ of total number of the households and 488 units in 2016 or $16 \%$ and this is less for $41.62 \%$. 
Table 2. Land funds

\begin{tabular}{|c|c|c|c|c|}
\hline \multirow{2}{*}{\begin{tabular}{|c|} 
LAND FUNDS \\
$\begin{array}{c}\text { Size of the holdings according to the size } \\
\text { of property }\end{array}$ \\
\end{tabular}} & \multicolumn{4}{|c|}{ Years } \\
\hline & 1991 & 2003 & 2010 & 2016 \\
\hline \multicolumn{5}{|c|}{ Available land (000) ha } \\
\hline Total available land in ha & 67176 & 42553 & 46836 & 49805 \\
\hline Up to 5 ha & 3383 & 2797 & 3144 & 3395 \\
\hline From 5-10 ha & 5302 & 2981 & 3314 & 3265 \\
\hline From $10-15$ ha & 3564 & 1788 & 1684 & 2140 \\
\hline Over15 ha & 54927 & 34987 & 33494 & 41005 \\
\hline Per holding & 25,26 & 19,52 & 20,52 & 22,21 \\
\hline Per farmer & 15,78 & 17,18 & 16,03 & 17,31 \\
\hline \multicolumn{5}{|c|}{ Agricultural land (000) ha } \\
\hline Total agricultural land in ha & 63674 & 32987 & 37172 & 35166 \\
\hline Up to 5 ha & 3388,25 & 1816,6 & 2428,3 & 2358,22 \\
\hline From $5-10$ ha & 51854 & 2164 & 2431,4 & 2079,81 \\
\hline From $10-15$ ha & 5053,15 & 1319 & 1392 & 1381,32 \\
\hline Over15 ha & 23,94 & 27412 & 30920 & 29347,32 \\
\hline Per holding & 3378,54 & 14,92 & 16,28 & 15,68 \\
\hline Per farmer & 14,96 & 17,18 & 16,03 & 17,31 \\
\hline \multicolumn{5}{|c|}{ Arable land (000) ha } \\
\hline Total arable land in ha & 18713 & 8133 & 9333 & 9456 \\
\hline Up to 5 ha & 3250,16 & 1760 & 2319,7 & 2256,13 \\
\hline From 5-10 ha & 4169,43 & 1843 & 2073,6 & 2131,34 \\
\hline From $10-15$ ha & 2372,90 & 1039 & 1067,7 & 1088,38 \\
\hline Over 15 ha & 8919,87 & 3493 & 3872,1 & 3980,18 \\
\hline Per holdings & 7,03 & 3,68 & 4,08 & 4,21 \\
\hline Per farmer & 4,39 & 3,28 & 3,19 & 3,28 \\
\hline \multicolumn{5}{|c|}{ Meadows $(000)$ ha } \\
\hline Total meadow in ha & 16739 & 8015 & 9146,5 & 8977 \\
\hline Up to 5 ha & 3071,76 & 1830 & 1941,9 & 2230,08 \\
\hline LAND FUNDS & \multicolumn{4}{|c|}{ Years } \\
\hline $\begin{array}{c}\text { Size of the holdings according to the size } \\
\text { of property }\end{array}$ & 1991 & 2003 & 1991 & 2016 \\
\hline \multicolumn{5}{|c|}{ Meadows (000) ha } \\
\hline From 5-10 ha & 7974,87 & 1957 & 2043,8 & 1532,47 \\
\hline From $10-15$ ha & 3558,89 & 1096 & 1042 & 1090,80 \\
\hline Over 15 ha & 6,29 & 3132 & 3818,3 & 3543,87 \\
\hline Per holding & 2125,96 & 3,62 & 4,00 & 4,00 \\
\hline Per farmer & 3,93 & 3,23 & 3,13 & 3,12 \\
\hline \multicolumn{5}{|c|}{ Pastures (000) ha } \\
\hline Total pastures in ha & 44953 & 24854 & 27839 & 25710 \\
\hline Up to 5 ha & 134,84 & 57,39 & 56,6 & 104,37 \\
\hline From 5-10 ha & 876,59 & 321 & 357,4 & 418,81 \\
\hline From $10-15$ ha & 1002,47 & 280 & 323,85 & 365,08 \\
\hline \multicolumn{5}{|c|}{ Pastures (000) ha } \\
\hline Over 15 ha & 42926,4 & 23919 & 27049,1 & 24822 \\
\hline Per holding & 10,56 & 11,24 & 12,19 & 11,46 \\
\hline
\end{tabular}

Source: Population, households, dwellings and agricultural holdings Census in 1991 and 2003, Agriculture Census 2010- structure of agricultural holdings, Press release No. 234: "Structure of agricultural holdings in 2016 (p) 1", Statistical Office - MONSTAT 
Table 2. illustrates that the total available land in 2016 amounted to 49805 ha, which is $25.85 \%$ less compared to 1991. The largest share of land in both 2016 and 1991 was in the category of over 15 ha. The total available land per farm in 2016 was 22.21 ha and in 1991 it was 25.21 ha, which is $11.90 \%$ less compared to 1991 . The average farm size in the EU is 17 ha, in Montenegro 6 ha and in the Durmitor area is 15 ha, which indicates approximately the same farm size as the EU, and 2.5 times larger than the national average in Montenegro. Agricultural land in 2016 amounted to 35,166 ha or $70.60 \%$ of the total available. Compared to 1991 , when that number was 63674 , it is $44.77 \%$ less. The largest share of agricultural land in both cases is in the category of land over 15 ha. Agricultural land per farm in 2016 amounted to 15.68 ha while in 1991 it was 23.94 ha, which is $34.50 \%$ less. Agricultural land per farmer in 2016 amounted to 17.31 ha, while in 1991 it was 14.96 ha, which is $13.57 \%$ less. The agricultural area per agricultural inhabitant in the EU is 7.47 ha, in the Alpine countries (Austria and Switzerland $8.50 \mathrm{ha}$ ) in Montenegro is 4.25 and in the Durmitor area 17.31 ha, which is 2.42 times more than in the EU and the Alpine countries and 4.25 times more than in Montenegro. This is a great comparative advantage of the Durmitor area. Arable land in 2016 amounted to 9456 ha or $26.88 \%$ of the total agricultural. Compared to 1991 when the number was 18713 ha, it is less for $49.46 \%$. The highest share of arable land for all observed years is in the category of over 15 ha.

Arable land per farm in 2016 amounted to 4.21 ha, while the same in 1991 amounted to 7.03 ha, which is $40.11 \%$ less. Arable land per farmer in 2016 amounted to 3.28, while the same in 1991 was 4,39 ha which is $25,28 \%$ less. The largest share is in the category over 20 ha. Arable land per farm is 9.49 ha, in the Alpine countrie 6.80 ha, in Montenegro 2.37 ha, and in Durmitor area 4.21 ha. This shows that the arable area is 2.25 times smaller on the Durmitor compared to the EU and 1.61 times less compared to the Alpine countries. While it is 1.77 times bigger compared to Montenegro. Meadows in 2016 amounted to 8977 ha or $25.52 \%$ of the total agricultural land. Compared to 1991 , when that number was 16739 ha, it is $46.37 \%$ less. The highest share in both years is in the category of over 20 ha. Meadows per farm in 2016 amounted to 4.00 ha, while in 1991 the amount was 6.29 , which is $36.40 \%$ less. Meadows per farmer in 2016 were 3.12 and in 1991 were 3,93 ha or 20.61\% less. The area of meadows per farm in the EU is 5.31 ha in the Alpine countries from 7.32 to 10.48 ha. In Montenegro it is 1.88 ha, while in the Durmitor area it is 4 ha. Compared to the EU, they are approximately the same and compared to the Alpine countries 2 times smaller and 2 times larger compared to Montenegro. The total share of pastures is 25710 ha, which represents $73.11 \%$ of the total agricultural land in 2016. Compared to 1991, when the number was 44953 ha, it is less by $42.80 \%$. The highest share of pastures in both years is in the category of over 20 ha. Pastures per farm in 2016 amounted to 11.46 ha, which is compared to 1991 , decrease of $32.18 \%$, when that number was 16.90 ha. Pastures per farmer amounted to 8.93 ha in 2016, which is $15.43 \%$ less compared to 1991 , when that number was 10,56 ha. The area of pastures per farm in the EU is 5.67 ha, in the Alpine countries is about 10 ha, in Montenegro 3.21 ha, while in the Durmitor area it is 11.46 ha. Compared to the EU it is 2.02 times even larger than the Alpine countries, and 3.57 times more than Montenegro. 
Table 3. Livestock fund-cattle breading

\begin{tabular}{|c|c|c|c|c|}
\hline CATTLE & 1991 & 2003 & 2010 & 2016 \\
\hline NUMBER OF HOUSEHOLDS WITH CATTLES & 1832 & 1535 & 1460 & 1385 \\
\hline Number of cattle in $(000)$ & 21138 & 8552 & 7629 & 7138 \\
\hline Number of cattle per household & 11,53 & 5,57 & 5,22 & 5,18 \\
\hline Number of cattle on 100 ha of & 11,28 & 25,99 & 20,56 & 21,77 \\
\hline Number of cattle per ha of arable surface & 1,12 & 0,34 & 0,27 & 0,27 \\
\hline Number of cattle per ha of meadow & 0,47 & 0,34 & 0,27 & 0,27 \\
\hline \multicolumn{5}{|l|}{ HOUSEHOLDS PER NUMBER OF CATTLE } \\
\hline $1-2$ & 437 & 362 & 429 & 337 \\
\hline $3-4$ & 596 & 563 & 513 & 505 \\
\hline $5-6$ & 359 & 279 & 216 & 238 \\
\hline $7-8$ & 252 & 175 & 132 & 149 \\
\hline$>8$ & 182 & 154 & 167 & 153 \\
\hline \multicolumn{5}{|l|}{ HOUSEHOLDS WITH COWS } \\
\hline $1-2$ & 516 & 750 & 601,52 & 549 \\
\hline $3-4$ & 926 & 710 & 673,6 & 745 \\
\hline $5-6$ & 261 & 59 & 172,28 & 101,90 \\
\hline$>7$ & 128 & 13 & 94,9 & 26,31 \\
\hline CATTLE & 1991 & 2003 & 2010 & 2016 \\
\hline \multicolumn{5}{|l|}{ NUMBER OF CATTLE PER CATEGORY } \\
\hline Total & 21138 & 8552 & 7629 & 7183 \\
\hline Calf and young cows & 6271,64 & 2373 & 3067 & 1424 \\
\hline Cows and pregnant cows & 13471 & 5209 & 4113 & 5490 \\
\hline Oxen and bull & 1392 & 970 & 449 & 269 \\
\hline \multicolumn{5}{|c|}{ AGRICULTURAL HOUSEHOLDS PER NUMBER OF CONDITIONAL HEADS } \\
\hline Total & 15735 & 6772 & 5328 & 6115 \\
\hline Number of households & 1832 & 1535 & 1460 & 1385 \\
\hline Cows & 13471 & 5209 & 4113 & 5490 \\
\hline \multicolumn{5}{|l|}{ CONDITIONED HEADS PER HOUSEHOLD } \\
\hline Total & 8,58 & 4,71 & 3,64 & 4,41 \\
\hline Cows & 7,35 & 3,39 & 2,81 & 3,96 \\
\hline
\end{tabular}

Source: Population, households, dwellings and agricultural holdings Census in 1991 and 2003, Agriculture Census 2010- structure of agricultural holdings, Press release No. 234: "Structure of agricultural holdings in 2016 (p) 1", Statistical Office - MONSTAT

It is visible from the Table 3. that number of households with cattle in 2016 was 1385 and in 1991 was 1832 which is for $24.39 \%$ less. The largest representation of the households in both years is in land category of 1-3ha. The number of cattle in 2016 was 7183 and in 1991 this was 21138 , or for $66.01 \%$ less. The largest representation of cattle in 2016 was in category of land over 20 ha and in 1991 it was in category of 3-5ha.

Number of cattle per household in 2016 was 5.18 heads, while in 1991 this was 11.53 heads which is for $55.07 \%$ less. Number of cattle on 100ha of surface in 2016 was 21.77 heads and in 1991 this was 11.28 heads. Number of cattle per ha of arable land in 2016 was 0.75 heads and in 1991 this was 1.12 heads, or $33 \%$ more when compared with 2016. Number of cattle per ha of meadow in 2016 was 0.27 heads and in 1991 this was 0.47 heads, or $42.53 \%$ less than in 2016 . Households per number of cattle are the most represented in category of 3-4 heads of cattle and this was 505 heads in 2016 and 596 heads in 1991, or $15.26 \%$ less. As well, the number of households with cows is the most 
represented in category of households of 3-4 heads of cattle. This was 745 heads in 2016 and 926 heads in 1991, or 19.54\% less. Number of cattle according to categories illustrates the largest representation of cows and pregnant cows in total number in 2016 that was 5490 or $76.43 \%$ and in 1991 this number was 13471 heads, or $63.72 \%$ of total number.

Agricultural households per number of conditioned heads in 2016 were 1385 and in 1991 were 1832 , or $24.39 \%$ less. Total number of conditioned heads of cattle in 2016 was 6115 heads and in 1991 it was 15735 heads or $61.13 \%$ less. Total number of conditioned heads per household in 2016 was 4.41 heads and in 1991 this was 8.58 heads or $48.60 \%$ less. Number of cattle heads per EU household is 5.86 and in Alps countries 20 heads, in Montenegro 1.94, and on Durmitor territory this is 5.18 heads of cattle. In comparison with EU this is at the same level, and with Alps countries this parameter value is 4 times lower or 2.67 times higher than in Montenegro.

Table 4. Livestock fund- sheep breeding

\begin{tabular}{|c|c|c|c|c|}
\hline SHEEP & 1991 & 2003 & 2010 & 2016 \\
\hline NUMBER OF HOUSEHOLDS WITH SHEEP & 688 & 368 & 496 & 350 \\
\hline Number of sheep in $(000)$ & 84037 & 25684 & 36986 & 21065 \\
\hline Number of sheep per household & 122 & 69 & 74 & 60 \\
\hline Number of sheep on 100 ha of agricultural surface & 132 & 78 & 99 & 63 \\
\hline Number of sheep per ha of arable surface & 4,49 & 3,15 & 3,96 & 2,22 \\
\hline Number of sheep per ha of meadow & 1,86 & 1,03 & 1,32 & 0,81 \\
\hline \multicolumn{5}{|l|}{ HOUSEHOLDS PER NUMBER OF SHEEP } \\
\hline 10 & 20,56 & 7,84 & 14,1 & 10 \\
\hline \multicolumn{5}{|l|}{ HOUSEHOLDS PER NUMBER OF SHEEP } \\
\hline $20-50$ & 294 & 93,85 & 139,85 & 136 \\
\hline $60-100$ & 183 & 99,24 & 134,87 & 116 \\
\hline $110-150$ & 129 & 91,98 & 119,38 & 62 \\
\hline$>150$ & 60 & 74,8 & 87,59 & 26 \\
\hline \multicolumn{5}{|l|}{ HOUSEHOLDS WITH SHEEP FOR MILKING } \\
\hline 10 & 28,20 & 13,8 & 14,08 & 10,67 \\
\hline $20-50$ & 317,44 & 112,6 & 151,08 & 144 \\
\hline $60-100$ & 201,58 & 105,8 & 156,43 & 128 \\
\hline $110-150$ & 92,87 & 97,40 & 132,77 & 66,5 \\
\hline$>150$ & 48,16 & 38,89 & 40,82 & 0,105 \\
\hline \multicolumn{5}{|l|}{ NUMBER OF SHEEP PER CATEGORIES } \\
\hline Total & 84018 & 25684 & 36986 & 21065 \\
\hline Lambs & 21353 & 4676 & 16834 & 7485 \\
\hline Breeding sheep & 59657 & 18285 & 18965 & 12692 \\
\hline Other sheep & 3008 & 2723 & 1187 & 888 \\
\hline \multicolumn{5}{|c|}{ AGRICULTURAL HOUSEHOLDS PER NUMBER OF CONDITIONED HEADS } \\
\hline Number of households & 688 & 368 & 496 & 350 \\
\hline Sheep for milking & 5965 & 1828 & 1896 & 1269 \\
\hline Total & 8403 & 2568 & 3698 & 2106 \\
\hline \multicolumn{5}{|l|}{ CONDITIONED HEADS PER HOUSEHOLD } \\
\hline Total & 12,21 & 6,97 & 7,45 & 6,01 \\
\hline Sheep for milking & 8,67 & 4,96 & 3,82 & 3,62 \\
\hline
\end{tabular}

Source: Population, households, dwellings and agricultural holdings Census in 1991 and 2003, Agriculture Census 2010- structure of agricultural holdings, Press release No. 234: "Structure of agricultural holdings in 2016 (p) 1", Statistical Office - MONSTAT 
Number of households with sheep in 2016 was 350 households and the most were in category of over 20 heads. In 1991 the number of households with sheep was 688 or 49.12\% more in comparison with 2016. Number of sheep in 2016 was 21065 heads and mostly were in the land category of 5-8ha while this number in 1991 was 84037 or $74.93 \%$ less. Number of sheep per household in 2016 was 60 heads and in 1991 this was 122 heads or $50.81 \%$ more when compared with 2016. Number of sheep on 100 ha of agricultural surface in 2016 was 63 heads of sheep and in 1991 this was 132 heads or $52.27 \%$ less. Number of sheep per ha of arable land in 2016 was 2.22 heads and in 1991 this was 4.49 heads or $50.55 \%$ more in comparison with 2016 . Number of sheep per ha of meadow in 2016 was 0.81 heads and in 1991 this was 1.86 heads or $56.45 \%$ less. Households in accordance with number of sheep show higher representation in group of 20-50 heads of sheep and there were136 households in 2016, while in 1991 there were 294 households or $53.74 \%$ less, more. Households with milking sheep were the most represented in the group of 20-50 heads of sheep and there were 144 households in 2016, while in 1991 there were 317 households or $54.57 \%$ less. Regarding the number of sheep per categories it was observed that the most numerous had been category of breeding sheep, and in 2016 this number was 12692, while in 1991 this was 59657 heads of sheep or $78.72 \%$ more when compared with 2016.

Agricultural households per number of conditioned heads in 2016 were 350 and in 1991 were 688 heads or 49.12\% less. Number of conditioned heads per household in 2016 was 6.01 and in 1991 this was 12.21 or $50 \%$ less. Number of head of sheep per household in EU is 0.87, in Alps countries 0.50 heads, in Montenegro 4.19 heads, and on Durmitor territory 60 heads of sheep. When compared with EU and Alps countries this is 60 times more and when compared with Montenegro it is 15 times more.

Comparative data relating to the Alpine countries, the EU and Montenegro are presented in detail in the following table.

Table 5. Statistical indicators of the agrarian structure of Alpine countries, EU and Montenegro

\begin{tabular}{|c|c|c|c|c|c|c|c|}
\hline Statistical indicators & 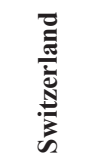 & 选 & 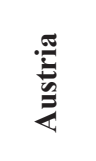 & $\stackrel{\frac{\pi}{\pi}}{\Xi}$ & 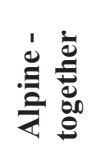 & 로 & 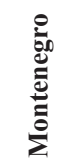 \\
\hline Size of agricultural holdings (ha) & 17,72 & 42,00 & 17,00 & 6,1 & 20,70 & 17,00 & 6,00 \\
\hline $\begin{array}{l}\text { Agricultural areas per agricultural } \\
\text { population (ha) }\end{array}$ & 8,59 & 29,56 & 8,65 & 3,88 & 12,67 & 7,47 & 4,25 \\
\hline Arable land per holdings (ha) & 6,85 & 27,86 & 6,89 & 3,25 & 11,21 & 9,49 & 2,37 \\
\hline Meadow area per holdings (ha) & 10,48 & 12,07 & 7,23 & 1,59 & 7,99 & 5,31 & 1,88 \\
\hline Pasture area per holdings (ha) & 10,86 & 15,70 & 9,76 & 2,02 & 9,58 & 5,67 & 3,21 \\
\hline $\begin{array}{l}\text { Number of head of cattle per } \\
\text { holdings }\end{array}$ & 19,69 & 20,87 & 0,2 & 0,31 & 10,26 & 5,86 & 1,94 \\
\hline $\begin{array}{l}\text { Number of head of sheep per } \\
\text { holdings }\end{array}$ & 0,73 & 1,12 & 0,2 & 0,31 & 0,59 & 0,87 & 4,19 \\
\hline
\end{tabular}

Source: Eurostat (2017). Questionnaire about farm structure 


\section{Conclusion}

During the research, relevant issues related to the perception of tendencies and factors that affect the constitution of the ownership structure and its impact on agricultural production were analyzed. Under the influence of the general trends, significant changes were made in the agrarian and ownership structure of land areas on rural farms. There were periodic changes in all land areas, especially in 2003, when there was a large decrease compared to 1991, so that this trend went upwards from 2003 to 2010. When there was an increase, and from that year to 2016, the trend of decreasing land areas continued. The exception to this was arable land, where after the fall in the period from 1991 to 2003, there was a constant increase ofareas. In the total agricultural area, meadows and pastures occupy over $90 \%$, with a more dominant share of pastures, which led to livestock-dominated extensive production. In accordance with the established hypothesis, it is concluded that the highest concentration of households according to the ownership structure of land areas is in the category over 15 ha, which confirms the same that these are properties with larger land areas. In the researched area, there was a decreasing trend in the number ofcattle on rural holdings, especially in 2003 compared to the baseline, when this trend was most emphasised. Also, the size of the holdings significantly determined the changes in the share of the number of cattle in average per farm and per hectare of land used. Throughout all analyzed annual periods, it was noticed that the highest concentration of farms was according to the number of farms with cattle and according to the number of cattle in the category of 3-4 heads. Major changes also took place in the share of sheep breeding. The total number of sheep significantly decreased, as well as the number of sheep farms compared to 1991, and especially in 2003. The largest share of farms according to the number of sheep and sheep for the milking was in the category of 20 to 50 heads. In the Durmitor area, according to this research, there was a significant connection between the general tendencies of socio-economic development and changes in the ownership structure of agricultural holdings. This correlation was indicated by changes in the socio-economic holdings structure under the influence of economic development and deagrarization.

\section{Conflict of interests}

The authors declare no conflict of interest.

\section{References}

1. Alexandrov, A. (2016). The Bulgarian mountain agricultural resources, International conference. Sustainable development of mountain areas-experiences, challenges and perspectives, Žabljak, Montenegro, 33-35.

2. Bogdanov, N. (2016). Rural development and rural policy. Institute of Economics, Belgrade.

3. Cvijanović, G. (2015). Management of organic plant production.Institute for Agricultural Economics, Belgrade. 
4. Cvijanović, D., Popović, V., \& Subić, J. (2014). State and possibilities of development of sustainable agriculture and rural development in the Danube region. Institute for Agricultural Economics, Belgrade.

5. Eurostat (2017). Questionnaire about farm structure 2015-2017.

6. Federal Statistical Office (1991). Population, households, dwellings and agricultural holdings Census (households, agricultural population, agricultural funds of households - municipalities and settlements). Federal Bureau of statistics, Beograd.

7. Lazarević, R., \& Stošić, M. (2016). Livestock breeding is a mainstay of the sustainable development of the mountainous area in Serbia.Academy of Engineering Sciences of Serbia, Belgrade.

8. Lazarević, R. (2018). Agriculture and village of Serbia in agroecological development. Academy of Engineering Sciences of Serbia, Belgrade

9. Marković, M., Marković, B., Dubljević, R., \& Radonjić, D. (2017). Mountain range agriculture. Manufacturers Manual. University of Montenegro, Biotechnical Faculty, Podgorica.

10.Marović, С̆. (2018). Agriculture and Village in Montenegro in the Transition Period (1990-2016).Vijesti, Podgorica.

11. Matej, O. (2016). Sustainable mobility in mountain regions-examples from the alps. International conference; Sustainable development of mountain areas-experiences, challenges and perspectives. Žabljak, 76-80.

12.Mihailović, B., \& Simonović, Z. (2016). Strategic planning for sustainable development of agriculture and rural areas in Serbia, Institute for Agricultural Economics, Belgrade.

13. Statistical Office (2007). Population, households and dwellings Census in 2003. Book 1.Agricultural funds 2007. Book 2. Agricultural holdings by activity and source of income 2007. Statistical Office - MONSTAT.Podgorica.

14. Statistical Office (2010). Structure of agricultural holdings. Book 1. Key variables land and livestock funds. Book 2. Livestock fund 2011. Book 3. Utilised land 2011. Book 4. Topics of special interest 2011. Book 5. Typology of agricultural holdings. Statistical Office - MONSTAT.Podgorica.

15.Statistical Office (2016). Press release No. 234: "Structure of agricultural holdings in 2016 (p) 1'. Statistical Office - MONSTAT.

16.Stijepović, D. (2018). Organizational-economic characteristics and production results in rural areas of durmitorian area. Sustainable primary agricultural production in Serbia - status, opportunities, limitations and a chance.Faculty of Biofarming, Bačka Topola, 78-86.

17.Šarović, R. (2017). Sociological survey of rural and family farms in Montenegro, Faculty of Philosophy, Nikšic, 30-36. 